\title{
Is the positive c-kit immunostaining associated with the presence of cells analogous to the intersticial cells of Cajal in the ciliary muscle?
}

\author{
A imunomarcação positiva para c-kit está associada com a presença de células \\ análogas às intersticiais de Cajal no músculo ciliar?
}

\author{
Jayter Silva Paula ${ }^{1}$ \\ Eduardo Soares Maia Vieira de Souza ${ }^{2}$ \\ Mariana Bellini Oliveira ${ }^{3}$ \\ Maria de Lourdes Veronese Rodrig'ues ${ }^{4}$ \\ Sérgio Britto Garcia ${ }^{5}$
}

Trabalho realizado no Departamento de Oftalmologia, Otorrinolaringologia e Cirurgia de Cabeça e Pescoço do Hospital das Clínicas de Ribeirão Preto - USP Ribeirão Preto (SP) - Brasil.

Professor Doutor do Departamento de Oftalmologia, Otorrinolaringologia e Cirurgia de Cabeça e Pescoço, Hospital das Clínicas de Ribeirão Preto, USP - Ribeirão Preto (SP) - Brasil.

Doutor em Oftalmologia na Universidade de São Paulo - USP - Ribeirão Preto (SP) - Brasil.

${ }^{3}$ Graduanda (bolsista de IC) do Hospital das Clínicas de Ribeirão Preto, USP - Ribeirão Preto (SP) - Brasil.

${ }^{4}$ Professor Associado do Departamento de Oftalmologia, Otorrinolaringologia e Cirurgia de Cabeça e Pescoço do Hospital das Clínicas de Ribeirão Preto, USP Ribeirão Preto (SP) - Brasil.

Professor Associado do Departamento de Patologia da Faculdade de Medicina de Ribeirão Preto, USP - Ribeirão Preto (SP) - Brasil.

Address to correspondence: Jayter Silva Paula. Departamento de Oftalmologia, Otorrinolaringologia e Cirurgia de Cabeça e Pescoço, Hospital das Clínicas de Ribeirão Preto - Campus - USP Av. Bandeirantes, 3.900

- Ribeirão Preto (SP) CEP 14049-900

E-mail: jspaula@fmrp.usp.br

Financial support: Part of this work was supported by CAPES and FAPESP.

Recebido para publicação em 26.08.2008

Aprovação em 04.12.2008

\begin{tabular}{l} 
ABSTRACT \\
\hline Purpose: Interstitial cells of Cajal were identified in the gastrointestinal \\
tract of several species, with close relation to the enteric nervous system. \\
Since it was recognized that interstitial cells of Cajal express the gene \\
product of c-kit, we performed immunohistochemistry for c-kit protein in \\
ciliary muscle specimens of monkeys' eyes. Methods: Eight eyes from \\
four adult male new world monkeys (Cebus apella) were studied. After \\
blocking endogenous peroxidase activity and nonspecific protein \\
binding, 1:100 dilution of mouse monoclonal antibody against c-kit \\
human oncoprotein was applied to tissues. Antigen-antibody reaction \\
was visualized using the avidin-biotinylated horseradish peroxidase \\
complex in each slide. Results: We observed some groups of fusiform \\
c-kit expressing cells located amongst muscle bundles of the ciliary \\
muscle. Otherpigmentcells and mastcells were alsoobserved. Conclusion: \\
C-kit expressing cells observed in the ciliary muscle of Cebus apella, \\
showed no similarity to melanocytes or mast cells and they could be \\
associated with their gastrointestinal interstitial cells of Cajal counterpart. \\
\hline
\end{tabular}

Keywords: Coiled bodies; Ciliary body; Enteric nervous system/physiology; Gastrointestinal motility/physiology; Proto-oncogene proteins c-kit; Cebus

\section{INTRODUCTION}

Interstitial cells of Cajal (ICC) were identified in the gastrointestinal (GI) tract over a century ago, and several possible functions were ascribed to these cells on the basis of their morphology and close anatomic relationships with smooth muscle cells and neurons ${ }^{(1)}$. The original studies describing the existence of a specialized cell type in the tunica muscularis of the GI were those of Cajal $^{(2)}$.

These cells are closely related anatomically and functionally to the enteric nervous system (ENS) ${ }^{(1)}$. Several studies have suggested that the differentiation of ICC is dependent on $\mathrm{ENS}^{(3)}$.

After the description of ICC in the gut wall, the presence of ICC-like cells has been demonstrated in the smooth muscle layers of various organs, such as the human ureter $^{(4)}$, rabbit portal vein ${ }^{(5)}$ and pancreas ${ }^{(6)}$.

For many years, no conclusive data were available about ICC being smooth muscle cells or fibroblasts. Recently, it was recognized that ICC express the gene product of c-kit, a proto-oncogene that encodes a tyrosine kinase receptor, $\mathrm{c}-\mathrm{kit}^{(7-8)}$. Labeling of kit receptors or $\mathrm{c}$-kit mRNA has 
provided an efficient way of identifying ICC throughout the GI tracts of several species, including human, using light microscopy $^{(9-10)}$.

Since ICC have been described in several tissues related with the autonomic nervous system, we performed immunohistochemistry for kit protein in monkey eye specimens to study the presence of these cells in the ciliary muscle.

\section{METHODS}

\section{Tissues}

Eight eyes from four adult male new world monkeys (Cebus apella), of 2.0 to $2.8 \mathrm{~kg}$ weight, were studied in agreement with statements of the "Principles of laboratory animal care" (NIH), the OPRR Public Health Service Policy on the Humane Care and Use of Laboratory Animals, the U.S. Animal Welfare Act and the Ethics Committee of Animal Experimentation - Ribeirão Preto Medical School, University of São Paulo. The animals belonged to the Capuccin Monkeys Procreation Nucleus of the School of Odontology of Araçatuba, University of São Paulo. They were sacrificed by a lethal dose of pentobarbital sodium and the eyes fixed by perfusion via ascending aorta with $0.9 \%$ saline $\mathrm{pH} 7.0$, followed by $4 \%$ paraformaldehyde in $0.1 \mathrm{M}$ sodium acetate buffer $\left(\mathrm{pH} 6.0,4^{\circ} \mathrm{C}\right)$ and finally with $2 \mathrm{~L}$ of $4 \%$ paraformaldehyde in $0.1 \mathrm{M}$ sodium borate buffer $\left(\mathrm{pH} \mathrm{9.5,} 4^{\circ} \mathrm{C}\right)$. Both eyes were then enucleated and dissected into two horizontal halves. A fragment of the corneoscleral junction with iris and ciliary body was dissected from four different quadrants per eye in order to be histologically processed.

\section{Immunohistochemistry}

\section{C-kit}

Four- $\mu$ m thick sections were prepared from two paraffin blocks taken from the dissected fragments. One block was used for hematoxylin and eosin (HE) staining and for detailed histological examination and the other was used for immunohistochemistry ${ }^{(11-12)}$. After blocking endogenous peroxidase activity with $3 \%$ hydrogen peroxidase in methanol, sections were incubated for $40 \mathrm{~min}$ for antigen retrieval. After treatment with $10 \%$ normal goat serum for 10 min to block nonspecific protein binding, a 1:100 dilution of mouse monoclonal antibody against c-kit human oncoprotein (CD117, Novocastra Laboratories Ltd, Newcastle-upon-Tyne, UK) was applied to the tissues and the slides were kept overnight at room temperature.

\section{$S-100$}

After blocking endogenous peroxidase and nonspecific protein binding, a 1:800 dilution of rabbit policlonal antibody against S100 (S100 - Ab-2, Lab Vision, USA) was applied to the tissues and the slides were incubated for 60 minutes, at room temperature.

\section{Antigen-antibody reaction}

The antigen-antibody reaction was visualized in both assays using the avidin-biotinylated horseradish peroxidase complex (Novostain Super Kit ABC ${ }^{\mathrm{TM}}$, Universal, Novocastra Laboratories Ltd.) and diaminobenzidine as the chromogen (DAB, Zymed Laboratories, San Francisco, CA, USA). Positive and negative controls were performed as recommended by both laboratories.

Slides were counterstained with toluidine blue, in order to identify mast cells' metachromatic granules.

\section{RESULTS}

Some groups of elongated c-kit expressing cells with small perikarya and long branching processes were observed in at least three slides of each fragment. The positive c-kit cells with this specific format, characterized by multiple processes, were located among muscle bundles of the ciliary muscle and did not present toluidine blue metachromatic stain (Figure 1). The location and other observed features of these c-kit expressing cells may be associated with the counterpart of ICC in the GI tract.

Moreover, stained mast cells from the ciliary body stroma were found on all studied slides. They were confirmed specially by their histological features (Figures $2 a$ and $2 b$ ). Other pigment c-kit staining cells of the ciliary body included pigmented epithelium (Figure 2a). S-100 immunostaining cells were observed specially in the iris' stroma and displayed different format and tissue location (Figure 3).

\section{DISCUSSION}

In the deep muscular plexus, $\mathrm{Cajal}^{(2)}$ described cells with small perikarya and long, branching processes. On the basis of the staining characteristics of ICC with methylene blue and silver chromate, he believed ICC were a type of primitive neuron. In addition, these cells were located close to the nerve strands of the deep muscular plexus and those of the myenteric plexus.

Many of the ultrastructural features of ICC, including a basal lamina, smooth and rough endoplasmic reticulum, dense filaments, cell-to-cell contacts with other ICC and smooth muscle cells, and close contacts with nerve endings, seemed to exclude a nerve or connective tissue nature. Some investigators suggested that ICC are specialized or primitive smooth muscle cells, whereas others thought that ICC possessed the ultrastructural characteristics of fibroblasts ${ }^{(11)}$. To avoid ambiguity, the whole shape of a cell type as well as its relation to nerve and muscle should correspond closely to that originally described by Cajal.

The c-kit gene encodes a transmembrane receptor that has tyrosine kinase activity. C-kit plays a role in hematopoiesis, gametogenesis, and melanogenesis ${ }^{(13)}$. In fact, different cell types express c-kit, such as melanocytes and mast cells ${ }^{(13-14)}$. 
Immunohistochemical staining for c-kit became to be accepted as the best marker of ICC on light microscopy. This technique let to an undoubted differentiation between ICC and other local similar cells ${ }^{(7,9)}$.

We observed, in this study, the presence of some grouped fusiform c-kit expressing cells with small perikarya and long branching processes. We called these cells in the ciliary muscle as "ICC analogous". They are located amongst muscular bundles of the ciliary body. The presence of mast cells and melanocytes in the ciliary body was described in a previous study, with no description of local ICC ${ }^{(14)}$. That study described "large dendritic mast cells" with numerous long processes, in close association with nerve fibers. Since those c-kitexpressing cells showed no morphological and staining simi-

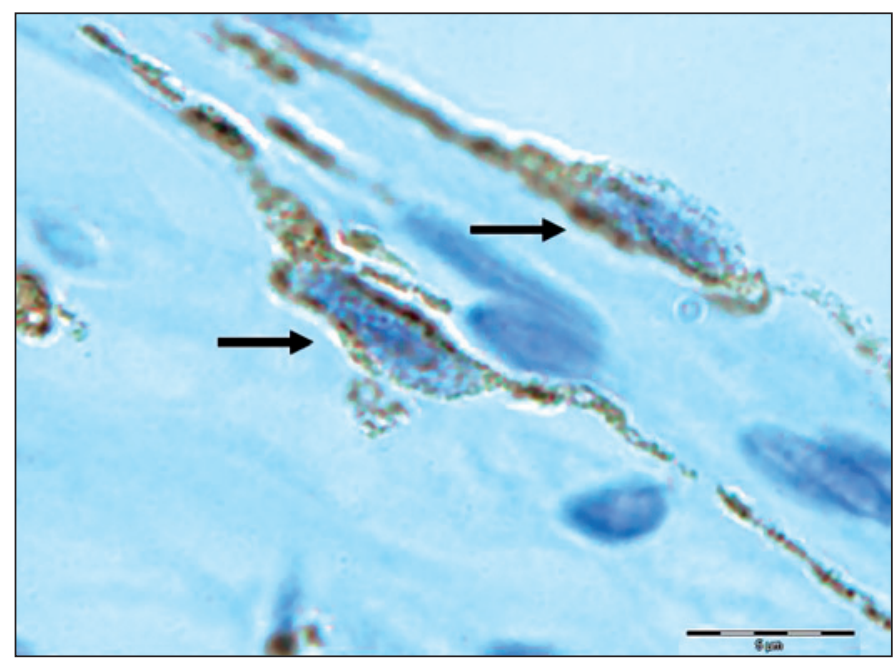

Figure 1 - Immunohistochemical localization of c-kit cells in the monkey ciliary muscle, showing possible interstitial cells of Cajal (ICC) analogous, with a fusiform shape (black arrows) and branches between muscular bundles; microphotography, X1000 larities to melanocytes or mast cells (observed with S-100 and toluidine blue, respectively), and were near nerve fibers, they could be associated with their ICC counterparts.

Some specific issues were not well elucidated and should be studied in order to confirm the rationale of the present data. These issues include in vitro physiological tests involving muscular activity, and double or triple identification of all cell types using conventional immunofluorescence assays and serial confocal microscopy.

Until recently, the function of ICC has been speculative and not based on physiological tests. C-kit labeling has improved the understanding of the anatomic relationships between ICC and enteric neurons, smooth muscle cells, and other resident cells in the tunica muscularis. Some physiological studies showed that ICC are involved in the development of electrical rhythmicity and in the regulation of a GI pacemaker system ${ }^{(15-16)}$.

Moreover, there is evidence suggesting that ICC are essential for rhythmic slow waves of the smooth muscle layers of the small intestine $e^{(1,16)}$.

Because of the close relationship between ICC and ENS of the GI tract ${ }^{(16)}$, we hypothesize that ciliary body ICC analogues could be associated with a sort of physiological mechanism involving the autonomic nervous system and ciliary muscle function, such as maintenance of basal muscle tonus in visual accommodation.

The present study discusses for the first time the possible presence of c-kit-positive ICC in the normal monkey ciliary muscle. It may be hypothesized that a lack of ICC in the ciliary muscle could contribute to dysfunction of this muscle in the aging process in some species. Further studies are needed to confirm and refine the understanding of the relationship of the mechanisms of ICC and ciliary muscle function.
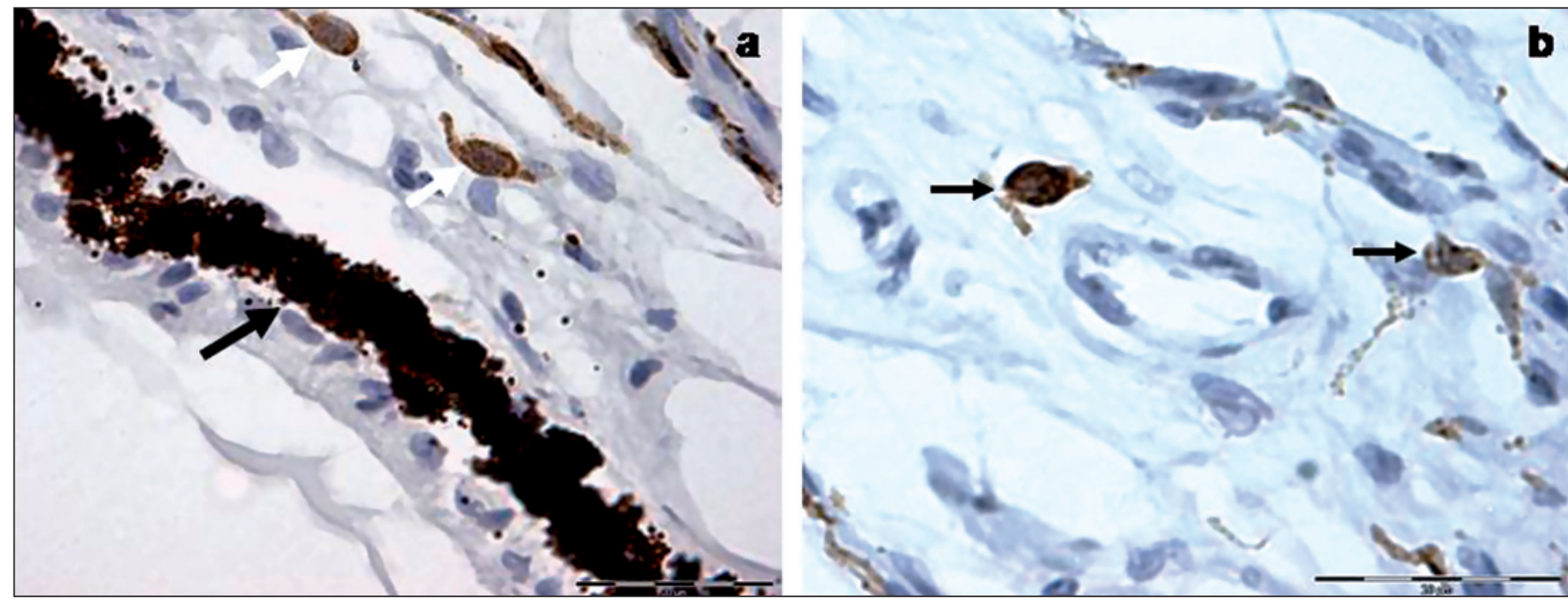

Figure 2 - Microphotography of other c-kit staining cells in the ciliary body of Cebus apella; a) note dark-staining cells in the pigmented epithelium (black arrow) and scattered intermediate-staining mast cells in the stroma (white arrows), X400; b) immunostained mast cells around blood vessels in the ciliary muscle (black arrows), $\mathrm{X} 400$ 


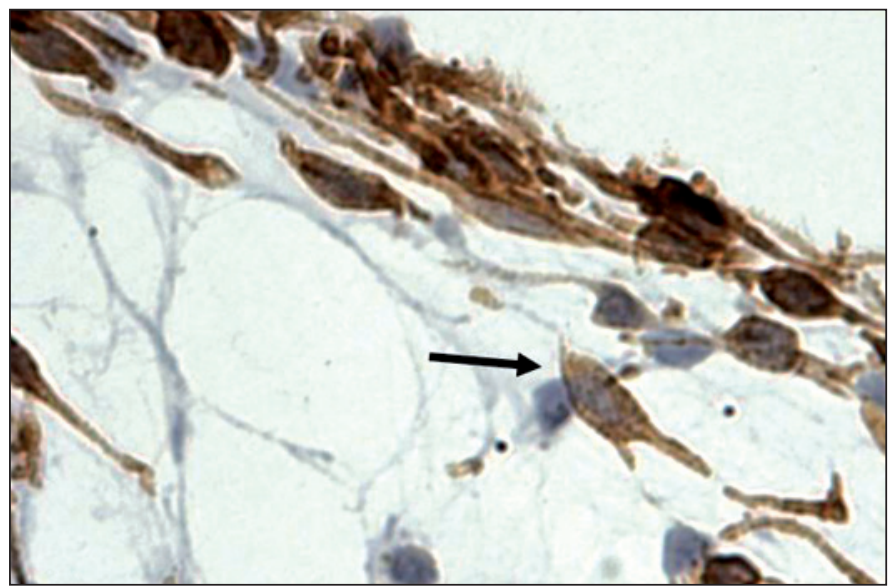

Figure 3 - S-100 immunohistochemistry displaying a typical melanocyte (black arrow) with shorter branches and abundant cytoplasm in the connective tissue of iris; microphotograph, X400

\section{CONCLUSIONS}

As immunohistochemical staining of characteristic c-kit cells is accepted as a marker of ICC on light microscopy, we accept that those elongated c-kit-expressing cells visualized in the ciliary muscle could be ICC analogous of the eye.

Functional experiments involving the accommodation process and double or triple immunostaining for c-kit and other local cells are the next step to study these hypotheses.

\section{ACKNOWLEDGEMENT}

The authors would like to thank Mrs R.O. Lopes for technical support and the Capuccin Monkeys Procreation Nucleus of the School of Odontology of Araçatuba, University of São Paulo for the animals.

\section{RESUMO}

Objetivo: As células intersticiais de Cajal estão presentes no trato gastrintestinal de diversas espécies animais, em íntima relação com o sistema nervoso entérico. Uma vez que as células intersticiais de Cajal expressam o produto do gene c-kit, realizou-se um ensaio imuno-histoquímico a fim de se verificar a marcação da proteína c-kit no músculo ciliar de amostras de olhos de macacos. Métodos: Oito olhos de quatro macacos do novo mundo (Cebus apella) foram estudados. Após bloqueio da peroxidase endógena e de ligação protéica não específica, os tecidos receberam aplicação de anticorpos de camundongos antioncoproteína c-kit humana (1:100). A reação antígeno-anticorpo foi verificada através da aplicação do complexo avidina-biotinilada-peroxidase em cada lâmina. Resultados: Foram observados grupos de células que expressam c-kit, localizadas entre as fibras do músculo ciliar. Mastócitos e outras células pigmentadas também foram observadas. Conclusão: Algumas células que expressam c-kit, observadas no músculo ciliar de Cebus apella, não mostraram similaridade com mastócitos ou melanócitos e podem ser classificadas como análogas das células intersticiais de Cajal gastrintestinais.

Descritores: Corpos enovelados; Corpo ciliar; Sistema nervoso entérico/fisiologia; Motilidade gastrointestinal/fisiologia; Proteínas proto-oncogênicas c-kit; Cebus

\section{REFERENCES}

1. Sanders KM. A case for interstitial cells of Cajal as pacemakers and mediators of neurotransmission in the gastrointestinal tract. Gastroenterology. 1996; 111(2):492-515.

2. Cajal SR. Histologie du système nerveux de l'homme et des vertébrés. Paris: Maloine. 1911.

3. Taguchi T, Suita S, Masumoto K, Nada O. Universal distribution of c-kitpositive cells in different types of Hirschsprung's disease. Pediatr Surg Int. 2003;19(4):273-9.

4. Metzger R, Schuster T, Till H, Stehr M, Franke FE, Dietz HG. Cajal-like cells in the human upper urinary tract. J Urol. 2004;172(2):769-72.

5. Povstyan OV, Gordienko DV, Harhun MI, Bolton TB. Identification of interstitial cells of Cajal in the rabbit portal vein. Cell Calcium. 2003;33(4): 223-39.

6. Popescu LM, Hinescu ME, Ionescu N, Ciontea SM, Cretoiu D, Ardelean C. Interstitial cells of Cajal in pancreas. J Cell Mol Med. 2005;9(1):169-90. Comment in: J Cell Mol Med. 2005;9(2):475; author reply 475; J Cell Mol Med. 2005;9(3):737; author reply 738-9.

7. Maeda H, Yamagata A, Nishikawa S, Yoshinaga K, Kobayashi S, Nishi K, Nishikawa S. Requirement of c-kit for development of intestinal pacemaker system. Development. 1992;116(2):369-75.

8. Torihashi S, Ward SM, Nishikawa SI, Nishi K, Kobayashi S, Sanders KM. C-kit-dependent development of interstitial cells and electrical activity in the murine gastrointestinal tract. Cell Tissue Res. 1995;280(1):97-111.

9. Huizinga JD, Thuneberg L, Kluppel M, Malysz J, Mikkelsen HB, Bernstein A. W/kit gene required for interstitial cells of Cajal and for intestinal pacemaker activity. Nature. 1995;373(6512):347-9.

10. Vanderwinden JM, Rumessen JJ, Bernex F, Schiffman SN, Panthier JJ. Distribution and ultrastructure of interstitial cells of Cajal in the mouse colon, using antibodies to kit and kit (W-lacZ) mice. Cell Tissue Res. 2000; 302(2): 155-70.

11. Komuro T. Comparative morphology of interstitial cells of Cajal: ultrastructural characterization. Microsc Res Tech. 1999;47(4):267-85.

12. Ibba Manneschi L, Pacini S, Corsani L, Bechi P, Faussone-Pellegrini MS. Interstitial cells of Cajal in the human stomach: distribution and relationship with enteric innervation. Histol Histopathol. 2004;19(4):1153-64.

13. Montone KT, van Belle P, Elenitsas R, Elder DE. Proto-oncogene c-kit expression in malignant melanoma: protein loss with tumor progression. Mod Pathol. 1997; 10(9):939-44.

14. May CA. Mast cell heterogeneity in the human uvea. Histochem Cell Biol. 1999;112(5):381-6.

15. Ward SM, Sanders KM. Physiology and pathophysiology of the interstitial cell of Cajal: from the bench to beside. I. Functional development and plasticity of interstitial cells of Cajal networks. Am J Physiol Gastrointest Liver Physiol. 2001;281(3):G602-11.

16. Takayama I, Horiguchi K, Daigo Y, Mine T, Fujino MA, Ohno S. The interstitial cells of Cajal and a gastroenteric pacemaker system. Arch Histol Cytol. 2002;65(1):1-26. 